by isotope dilution analysis than by gravimetric analysis when the patient is on penicillamine, possibly by exchange of the radioactive half-cystine residues with the mixed disulphide pool. Polarographic analysis using the cobalt-ammonium method does not distinguish between penicillamine disulphide and cystine (F. L. Warren, private communication). Paper chromatography can be used to demonstrate the decrease in cystine output, but these results are only semi-quantitative. Harris and Robson (1957) have shown that some relatives of cystinuric patients excrete about $200 \mathrm{mg}$. of cystine per g. creatinine. These individuals, who are presumed to be heterozygous for the cystinuria gene, do not form calculi, and therefore we did not think it necessary to reduce the cystine excretion of our patients below this level.

Clayton and Patrick (1961) used penicillamine in the treatment of cystinosis in the Lignac-de Toni-Fanconi syndrome, and reported improved growth, reduction of the blood pyruvate level, and some decrease in the generalized aminoaciduria. Subsequent studies have suggested that the excess cystine was probably acting as an enzyme inhibitor in that disease (Patrick, 1962), and it is possible that the cystine was being removed by a disulphide exchange with penicillamine. In the case of cystinuria, D-penicillamine reduced the cystine excretion but did not affect the excretion of the basic amino-acids.

The results reported in this paper confirm that it is possible substantially to reduce the urinary cystine output in cystinuria by oral administration of $\mathrm{D}$-penicillamine for periods of up to one year without any evidence of decreasing effectiveness of the treatment, and that the treatment has been free of any long-term side-effects over this period.

\section{Summary}

D-Penicillamine has been used to reduce the urinary cystine excretion in seven cystinuric patients. No effect on the excretion of the basic amino-acids was observed.

A diffuse morbilliform rash has been observed in three patients. This was controlled by steroid cover in the two patients to whom it was applied, and it was found possible to continue penicillamine therapy when the symptoms had subsided.

Most of these patients have continued on penicillamine therapy for periods ranging from a few months up to one year. No further side-effects have developed and there has been no evidence of further stone formation.

\section{REFERENCES}

Aposhian, H. V., and Aposhian, M. M. (1959). F. Pharmacol. exp. Ther., 126,131 .

Brigham, M. P., Stein, W. H., and Moore, S. (1960). F. clin. Invest., 39, 1633 .

Clarke, H. T., Johnson, J. R., and Robinson, R. (editors) (1949). Chemistry of Penicillin, p. 467. Oxford Univ. Press, London.

Clayton, B. E., and Patrick, A. D. (1961). Lancet, 2, 909.

Crawhall, J. C., Scowen, E. F., and Watts, R. W. E. (1963). Brit. med. 7., $1,588$.

Fowler, D. I., Harris, H., and Warren, F. L. (1952). Lancet, 1, 544. Goldber A., Smith, J. A, and Lockhead, A. C. (1963). Brit. med. F., 1,1270 .

Harris, H., and Robson, E. B. (1957). Amer. 7. Med., 22, 774.

Hess, W. C.! and Sullivan, M. X. (1935). F. biol. Chem., 108, 195.

Hirs, C. H. W. (1956). Ibid., 219, 611.

Levine, B. B. (1960). Nature (Lond.), 187, 940

Patrick, A. D. (1962). Biochem. F., 83, 248.

Scheinberg, I. H., and Sternlieb, I. (1960). Ann. intern. Med., 53, 1151.

Walshe, J. M. (1960). Ibid., 53, 1090.

\title{
Outbreaks of a Papulo-vesicular Exanthem on the Hands and Feet ("Summer-term Blains")
}

\author{
R. P. WARIN,* M.D., F.R.C.P. ; N. S. GALBRAITH, † M.B., D.P.H. ; N. H. H. GOLLEDGE, $\ddagger$ M.R.C.S., L.R.C.P. ; \\ S. P. HALL-SMITH,§ M.D., F.R.C.P.ED., M.R.C.P. ; A. E. K. PRICE,\| T.D., M.B., B.S. ; \\ P. G. MANN, I M.D., DIP.BACT. ; H. R. E. WALLIS,** M.D., M.R.C.P.
}

Brit. med. F., 1964, 1, 1413-1416

In May 1962, at a girls' boarding-school in Bath (school A), there was an outbreak of a papulo-vesicular rash on hands and feet involving 52 pupils out of a total of 271 . Two to three weeks later a similar outbreak occurred at another girls' boarding-school 15 miles ( $24 \mathrm{~km}$.) east of Bath (school B), affecting 38 pupils out of a total of 217. In May 1962, in the Hastings area, nine girls developed the same pattern of eruption: four from one girls' boarding-school, four from another girls' boarding-school, and one from a day school. In May 1963 a further outbreak of the same condition occurred at a co-educational boarding-school 20 miles $(32 \mathrm{~km}$.) south of Bristol (school C). There were 15 cases, all in girls, although the $\mathbf{2 7 0}$ pupils consisted of boys and girls in equal numbers.

In May 1963 four girls at school A and two at school B who had suffered from the eruption in 1962 developed it again. Also

\footnotetext{
* Consultant Dermatologist, Bristol. † Epidemiologist, Central Public Health La

₹ General Practitioner, Axbridge, Somerset.

II General Practitioner, Bath.

* Consultant Paediatrician, Bath. Dr. H. R. E. Wallis died before the paper was completed.
}

at this time an isolated case occurred in another girls' boardingschool in Bath.

\section{Clinical Features}

With the exception of two staff and two girls under 12, all the cases occurred in the 12-17 age-group, affecting chiefly girls aged 13-16. The rash was confined to the hands and fingers in $67 \%$, to the feet and toes in $8 \%$, and in $25 \%$ it was on both hands and feet. It occurred mainly on the backs of the fingers and toes but also on the fronts of the fingers, the hands, the borders of the feet, and the heels. In most girls the rash comprised between 5 and 10 lesions, but in some there were up to 50 .

The lesions were between 0.5 and $3 \mathrm{~cm}$. in diameter, raised, and dark red to purple in colour with some surrounding bluish erythema. Vesicles appeared in the centre in many and reached a size of $0.5-1 \mathrm{~cm}$. in diameter (Figs. 1-3). Particularly on the fronts of the fingers and hands, the vesicles developed a grey flaccid appearance. Some of the lesions ulcerated. There was slight itching, and some were painful and tender, and where 
they occurred over the joints the finger movements were stiff and painful. One girl had a large number of lesions on the hands, one or two of which suggested erythema multiforme although no really typical "target" lesions could be demonstrated. The condition lasted between two and four weeks, although the ulcerated lesions took longer to heal.

Among 76 of the girls involved, 5 (7\%) had one to three ulcers in the mouth which had the appearance of aphthous ulcers. In one of these girls the ulcers were noted a week before the appearance of the rash. In the other four they developed when the rash was present, but three girls had histories of

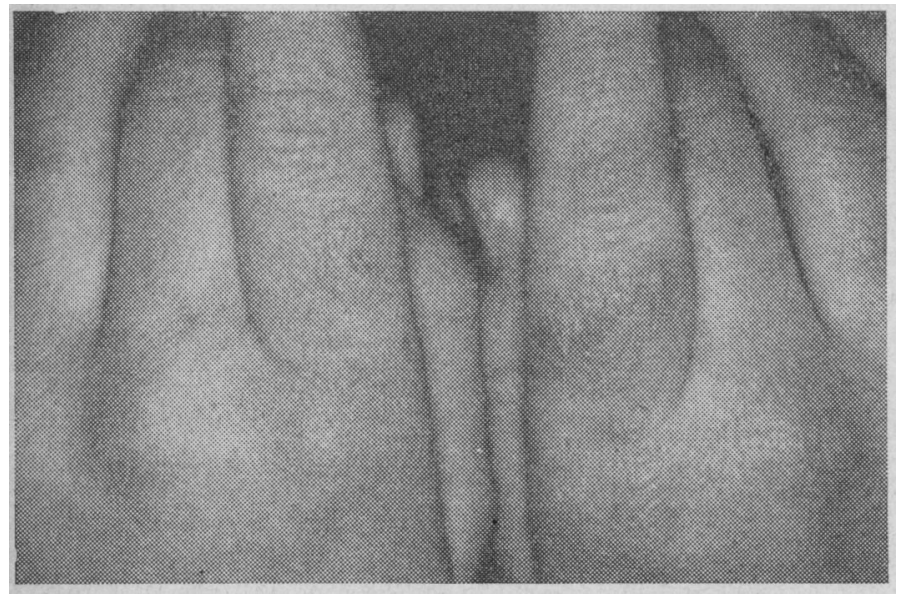

FIG. 1

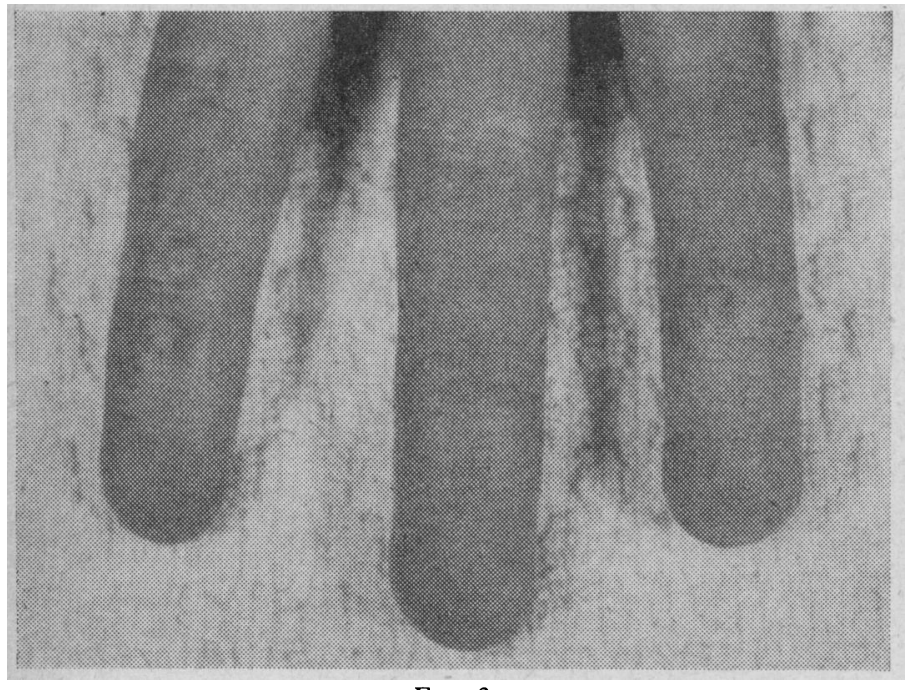

FIG. 2

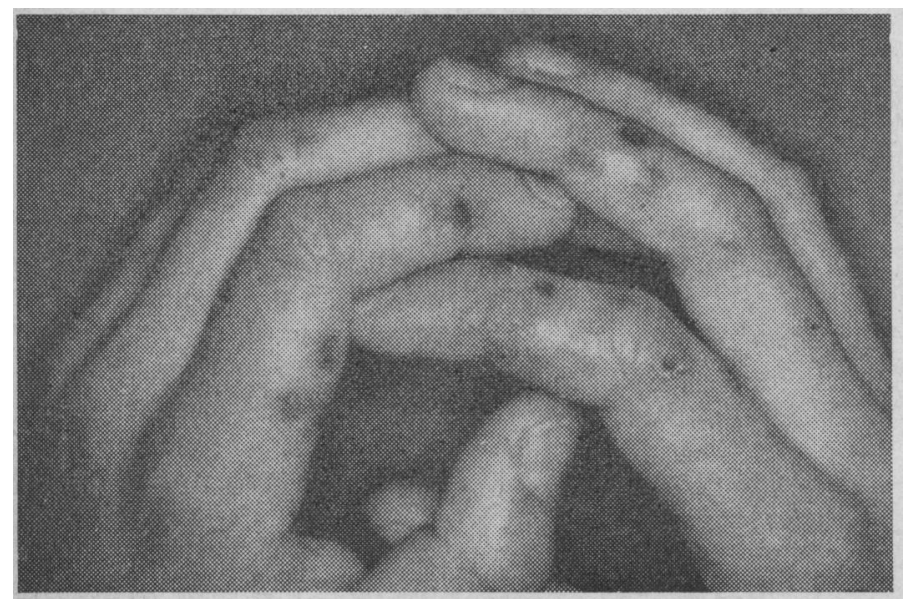

FIG. 3 having had repeated minor attacks of aphthous ulcers. One other girl developed a crusted lesion on the lips. None of the girls had a raised temperature, but a few of them complained of slight malaise. One girl had a sore throat a week before the rash; and another had a sore throat and headache a week after the rash began.

Inquiries from 76 girls revealed a previous history of winter chilblains in $40(53 \%)$. Although this seems a high proportion it is difficult to assess its significance because the incidence of a past history of chilblains in the unaffected girls was not known.

One girl gave a history of having had similar attacks in the summer term for three or four years, and six girls said they had had similar but less marked lesions in the previous year. One of these girls had been seen in 1961 by one of us (A. E. K. P.) and, in retrospect, obviously had the same condition.

\section{Epidemiology}

\section{Schools $A$ and $B$ (1962)}

Of 309 pupils and staff in school A, 53 (17\%) developed the disease and $40(16 \%)$ of 247 in school B. Ninety cases were in senior girls aged 12-17 years and only one was among the junior girls, who lived separately from the seniors in both schools; two cases were in members of the teaching staff (Table I). The disease was not localized to any class, residential house, or other group among the senior girls in either school. No other school in the area was known to have been affected and no cases came to notice in the general population.

Table I.-Attack Rates in Age-groups

\begin{tabular}{|c|c|c|c|c|c|c|}
\hline \multirow[t]{2}{*}{ Age-group } & \multicolumn{2}{|c|}{$\begin{array}{l}\text { School A } \\
\text { No. of Persons }\end{array}$} & \multicolumn{2}{|c|}{$\begin{array}{l}\text { School B } \\
\text { No. of Persons }\end{array}$} & \multicolumn{2}{|c|}{$\begin{array}{c}\text { Total } \\
\text { (Schools A and B) } \\
\text { No. of Persons }\end{array}$} \\
\hline & At Risk & Attacked & At Risk & Attacked & At Risk & Attacked \\
\hline $\begin{array}{l}\text { Junior girls under } 12 \\
\text { years } \\
\text { Senior girls } 12-17 \text { y ears } \\
\text { Teaching staff adults }\end{array}$ & $\begin{array}{r}53 \\
218 \\
38\end{array}$ & $\begin{aligned} 1(2) \\
51(23) \\
1(3)\end{aligned}$ & $\begin{array}{r}44 \\
173 \\
30\end{array}$ & $\begin{array}{l}0 \\
39(23) \\
1(3)\end{array}$ & $\begin{array}{r}97 \\
391 \\
68\end{array}$ & $\begin{array}{l}1(1) \\
90(23) \\
2(3)\end{array}$ \\
\hline $\begin{array}{l}\text { Total (pupils and teach- } \\
\text { ing staff) }\end{array}$ & 309 & $53(17)$ & 247 & $40(16)$ & 556 & $93(17)$ \\
\hline
\end{tabular}

Percentages are given in parentheses.

The school term began on $2 \mathrm{May}$, and within a week three girls in school A complained of "chilblains" on their hands. In one of these girls symptoms began at home during the holiday, but none of her family or other known contacts were similarly affected. The other two girls, who were in the same school house as the first case, developed symptoms after their return to school. The distribution of cases, by week of onset of symptoms, in school A, is shown in Table II. The onset of symptoms of the first case in school B was about 20 May, nearly three weeks after the first case in school $\mathrm{A}$, and the last case occurred in the first week in June.

TABLE II.-Week of Onset of Symptoms in 52* Cases in School A

\begin{tabular}{ll|l|c|c|c|c|c}
\hline $\begin{array}{l}\text { Week ending } \\
\text { No. of cases }\end{array}$. & $\ldots$ & 1 May & $8 \underset{2}{\text { May }}$ & $15 \underset{5}{\text { May }}$ & $22 \underset{24}{24}$ & $29 \underset{19}{\text { May }}$ & 5 June \\
\hline
\end{tabular}

The school term began on 2 May. * In one case the week of onset is not known.

Because the schools were situated 15 miles $(24 \mathrm{~km}$.) apart and the pupils had no direct contact with each other the possibility of a common source of the disease was investigated. The only person who was known to have visited both schools at the time of the outbreaks was a music mistress; she did not develop symptoms and none of her three pupils in school B was affected. The food supplies to the two schools were different, and within each school were common to senior girls, junior girls, and staff. Ice-cream, frozen foods, fresh meat, eggs, and butter came from 
different sources, and although some tinned foods were purchased from the same wholesaler they were from different manufacturers. The milk, which was pasteurized, came from different dairies and the water was from separate municipal supplies.

The disease was not apparently associated with the handling or application to the skin of an irritant soap or other substance ; it did not appear to be related to the handling of games equipment and towels common to many pupils, nor to direct contact of the hands such as occurred in dancing-classes.

\section{Hastings Schools (1962)}

The nine girls were all seen as hospital out-patients. Four were at one girls' boarding-school and four at another; one girl was at a day school in the area. Two further cases were reported from one of the boarding-schools but were not seen. All cases were seen during the last week of May and the first week of June. There was no particular link between the cases with regard to classes or houses.

\section{School C (1963)}

This is a school of about 270 pupils aged 11-18, consisting of boys and girls in equal numbers. There was considerable mixing of the sexes in school activities. The 15 affected were all girls, and no boys or any of the staff had any sign of the eruption. As this seemed so striking, announcements and detailed inquiries were made at the school, but no sign of the condition in the boys was discovered.

There was an even scatter between houses and forms. The outbreak began during the second week in May, one to two weeks after the beginning of the summer term. All the cases developed within a week of each other. There were no cases which antedated the main outbreak nor any which arose later.

\section{General (1962-3)}

At the time of the appearance of the Hastings cases a study of meteorological data showed that the mean temperature was from 3 to $6^{\circ} \mathrm{F}$. (1.7 to $3.3^{\circ} \mathrm{C}$.) below the average for the time of the year. There had been bright sunshine during the period, though the amount was also below average. At the time the cases were seen at schools $A, B$, and $C$ the weather was not remarkable, although school A seemed to be rather cold.

A feature of the outbreaks is the apparent absence of cases in the general population and in the other schools in the areas. Dermatologists and some general practitioners and school medical officers were informed, but only one similar case came to light. This was reported by Dr. Sheila Gough in a 17year-old girl who developed the eruption in May 1963. She was at a different girls' boarding-school in Bath.

During the periods in question no other outbreaks of any similar condition occurred in the Bath and Bristol areas. There was no notable increase in cases of erythema multiforme or of juvenile spring eruption.

\section{Virus Studies}

At school A throat swabs were collected from seven girls during the third week of illness. Vesicle fluid was also taken at the same time from four of these girls. Specimens of faeces were collected from six of the affected girls between four and six weeks after the date of onset. At school B faeces specimens only were obtained; samples from seven girls were taken between the fifth and tenth days of the disease. All material was tested by inoculation into day-old suckling mice and by culture on HeLa cells and monkey-kidney cells. The possi- bility of Coxsackie A virus was specifically considered, but no virus was recovered from any specimen. Faeces from three cases at school $\mathrm{C}$ in the second week of the eruption were examined by Dr. S. Clarke, but no enteroviruses were demonstrated.

\section{Discussion}

Thibierge and Rabut (1921) described nine cases of a similar eruption which they saw in Paris in May under the title of "une éruption papuleuse et prurigineuse développant au printemps sur les mains des jeunes sujets," and they mention that one or two cases of this condition had been seen in previous years in April and May. Although it is noted that several cases may occur in one family the patients were not otherwise associated. The patients ranged from 4 to 12 years of age; three were boys. The lesions were present on the backs of the hands and fingers, and in two cases on the nape of the neck and in two in the groins; they cleared in two to four weeks. Keining (1940) described a condition as "spring perniosis"; this affects the hands and backs of the fingers and also the ears. He compared this condition with autumn chilblains, pointing out that the spring chilblains affect the fingers and ears only.

Koehler (1938) recorded an outbreak of an unusual eruption which has some similar features. He observed 186 men from a German labour camp, 36 of whom developed an eruption in late April or early May. In 16 the lesions were on the hands alone, in 7 on the ears, and in 13 on both. The rash on the ears was typical of the condition known as "juvenile spring eruption," but from the description and photograph the eruption on the hands was very similar to that seen in our cases. None of the cases had lesions on the feet or mouth, and the condition cleared in 14 days. Koehler described the eruption as one of erythema exudativum multiforme, and thought that cold was an important factor.

Burckhardt (1942) recorded outbreaks in a school in Zurich of an eruption on the ears, in the spring of 1941 and of 1942. These occurred in a spell of unusually fine weather. Three out of 18 cases also had papules on the backs of the hands. Similarly, Anderson et al. (1954), when describing an outbreak of juvenile spring eruption which occurred in a holiday camp, reported that the 90 children affected had lesions on the ears typical of this condition, but one also had papules on the backs of the hands which from the description and photographs seem to have been very similar to the cases now reported. Juvenile spring eruption is much commoner in boys, whereas our cases were all girls and none had any lesions on the ears. Furthermore, in the co-educational school no boys were affected with either summer-term blains or ear lesions. However, it would seem that a similar condition can occur in association with juvenile spring eruption.

A few individual papules have suggested erythema multiforme, although no really classical "target" lesion could be demonstrated. It is, however, interesting that erythema multiforme can be precipitated by exposure to sunlight (Rasch, 1927 ; Hausmann and Haxthausen, 1929). The latter authors have also demonstrated that the incidence of erythema multiforme is greater in April, May, June, and July, with the peak in June, and seasonal recurrences are well recognized in this condition.

The distribution of the cases, in time, in school A, and the appearance of the second and third cases of the outbreak in the same school house as the first case, suggested that the disease was infectious and that it spread from case to case. It was improbable that the two outbreaks were directly related, because the only known association was the music mistress, who visited both schools, and she and her three pupils in school B were not affected.

The flaccid grey vesicles on the hands of some of the girls certainly resembled those described as " hand, foot, and mouth 
disease" in Toronto (Robinson et al., 1958), Birmingham (Alsop et al., 1960), California (Magoffin et al., 1961), Australia (Stewart, 1961), and Bristol (Flewett et al., 1963). The disease affected mainly children under 10 years; stomatitis was the main feature ; malaise and fever were present in up to half the cases; symptoms lasted less than seven days. The disease described in the present paper affected older children; mouth ulcers were present in five cases only, malaise was slight, there was no fever, and the illness lasted for two weeks or more. Moreover, no Coxsackie virus was isolated, whereas it had been readily demonstrated in the outbreaks of "hand, foot, and mouth disease."

The possibility that the disease was due to infection with bovine foot-and-mouth disease was considered. The vesicular rash on the hands and feet resembled that seen in human infection with foot-and-mouth disease virus, but the other two criteria for the diagnosis in man were absent-initial fever and vesicles on the lips and buccal mucosa (Arkwright, 1928). Most of the authenticated human infections have occurred in persons closely associated with sick cattle, but cases have also been reported after drinking raw milk from affected cows (Flaum, 1929). The girls in the outbreaks described had no known association with cattle infected with foot-and-mouth disease. The milk consumed in the schools was pasteurized, and there was no reported disease in cattle on the supplying farms or elsewhere in the district.

Much against an infective cause are the facts that only girls were involved, even when living in close contact with boys; seven girls had had a similar eruption in the preceding May, and six developed it again in the following May. Also no virus was discovered by laboratory methods which would have certainly demonstrated at least an enterovirus.

The other notable epidemiological feature of the disorder is the seasonal incidence. All the outbreaks, the previous attacks, the recurrences, and the isolated case have occurred in May or early June. Although no very unusual meteorological conditions were associated with the epidemics, it can be quite cold at times in May, and it is often the early summer sunlight which appears to have a bad effect on many dermatoses, in which there is an actinic causal factor. It is well known that herpes simplex lesions can be precipitated by unusual exposure to sunshine, and a possible explanation would be that seasonal climatic factors were acting in association with an unknown virus infection.

Many of the lesions have resembled chilblains, and over half the children affected have previously suffered from chilblains in the winter-time. Indeed, in those who have had attacks in previous summer terms this had apparently been the diagnosis. Although widespread chilblains can develop in a community, coincident with a sudden change in weather, it would seem very unlikely that such large epidemics would occur in May in the schools without numerous cases being noticed at the same time in the general population of the area. Also, although some lesions looked like chilblains the majority were too small, and many had the central grey flaccid blister which seems to be typical of summer-term blains.

It has been very difficult to think of a suitable name for the condition. Summer-term blains links the condition with the schools and the season. It also brings to mind the appearance of the lesions on fingers and toes but leaves the cause undecided.

\section{Summary}

A series of cases of an unusual eruption is described. The lesions occurred on the hands, fingers, feet, and toes, varying in numbers from 1 to 50 , and were $0.5-3 \mathrm{~cm}$. in diameter, raised and dark red to purple in colour. Grey flaccid vesicles appeared in the centre in many, and a few ulcerated.

The cases have occurred in three outbreaks affecting two girls' boarding-schools in and near Bath (1962, 92 girls) and one co-educational school near Bristol (1963, 15 girls). Isolated cases have been seen in the areas of Hastings (1962, nine girls) and Bath (1963, one girl). The main incidence occurred in the 12-16 age-group, and the eruption has not yet been seen in boys.

Six of the girls had suffered from a similar eruption in the preceding May and seven developed it again in the following May.

The outbreaks, isolated cases, previous attacks, and recurrences all occurred during May or the first week in June.

No viruses were demonstrated in spite of careful studies, particularly with regard to possible enteroviruses.

We are grateful to Dr. C. D. Evans and Dr. R. R. M. Harman for their help in the preparation of this paper.

\section{RBFERENCES}

Alsop, J., Flewett, T. H., and Foster, J. R. (1960). Brit. med. F., 2, 1708. Anderson, D., Wallace, H. J., and Howes, E. I. B. (1954). Lancet, 1, 755.

Arkwright, J. A. (1928). Ibid., 1, 1191.

Burckhardt, W. (1942). Dermatologica (Basel), 86, 85

Flaum, A. (1929). Acta path. microbiol. scand., 16, 197.

Flewett, T. H., Warin, R. P., and Clarke, S. K. R. (1963). F. clin. Path.

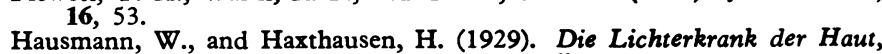
p. 106. Ürban and Schwarzenberg, Berlin.

Keining, E. (1940). Derm. Wschr., 110, 26.

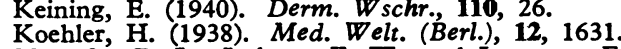

Magoffin, R. L., Jackson, E. W., and Lennette, E. H. (1961). F. Amer. med. Ass., 175, 441 .

Rasch, C. (1927). Proc. roy. Soc. Med., 20, 26.

Robinson, C. R., Doane, F. W., and Rhodes, A. J. (1958). Canad. med. Ass. F., 79, 615.

Stewart, A. K. M. (1961). Med. 7. Aust., 2, 394.

Thibierge, G., and Rabut, R. (1921). Paris méd., 2, 309. 